\title{
DYNAMICS OF HEMOSTASIS PARAMETERS AND ENDOTHELIAL DYSFUNCTION MARKERS IN PATIENTS WITH THERMAL INJURY
}

Morrison $\mathrm{W}^{1}$, Bozhedomov AYu ${ }^{2}$

${ }^{1}$ Saratov State Medical University, Saratov, Russia

2 Pirogov Russian National Research Medical University, Moscow, Russia

Burn injuries kill thousands of people. The aim of this study was to investigate the dynamics of systemic inflammatory response parameters, endothelial dysfunction markers and hemostasis impairment in patients with thermal burn injuries. The study was conducted in 51 patients aged 16 to 80 years presenting with moderate to severe thermal burns. The systemic inflammatory response was assessed based on the levels of tumor necrosis factor $\alpha$ (TNFa), a number of interleukins (IL6, IL12), the C-reactive protein, and the monocyte chemoattractant protein 1 (MCP-1). Hemostatic impairments were inferred from the results of coagulation tests that measured the activated partial thromboplastin time (APTT), the prothrombin index (PI), the prothrombin time (PT) and the platelet count. Endothelial dysfunction was analyzed based on the levels of vascular endothelial growth factor (VEGF), total endothelin (TE) and circulating endothelial cells. The dynamics of the listed parameters were studied over 45 days following the injury. Endothelial dysfunction markers peaked on days $3-15$ (VEGF $828.9 \pm 993.2 \mathrm{pg} / \mathrm{mL}, \mathrm{TE} 3.0 \pm 1.7 \mathrm{fmol} / \mathrm{mL}$, CEC $6.4 \pm 6.0 \cdot 10^{4} / \mathrm{l}, \mathrm{IL} 6264.4 \pm 131.2 \mathrm{pg} / \mathrm{mL}$, TNFa $41.4 \pm 111.9 \mathrm{pg} / \mathrm{ml}$, C-reactive protein $128.3 \pm 52.4 \mathrm{nmol} / \mathrm{mL}$ ). Coagulation was significantly impaired during the same period (APTT $41.4 \pm 17.7 \mathrm{~s}, \mathrm{PI} 83.6 \pm 15.4 \%$, PT $22.3 \pm 10.0 \mathrm{~s}$ ). By day 30-35, blood concentrations of proinflammatory cytokines and inflammation mediators had declined (TNFa $3.9 \pm 9.6 \mathrm{pg} / \mathrm{mL}$, IL6 $49.0 \pm 35.9 \mathrm{pg} / \mathrm{mL}$, C-reactive protein $81.9 \pm 341 \mathrm{nmol} / \mathrm{ml}$ ); in that phase, the coagulation potential was continuing to decrease (APTT $51.8 \pm 34.1 \mathrm{~s}, \mathrm{PI} 82.9 \pm 19.4 \%, \mathrm{PT} 24.9 \pm 21.4 \mathrm{~s}$ ). The study demonstrates that damage to the endothelium results from both injured tissue breakdown and inflammation mediators. The risk of thromboembolic and hemorrhagic complications is the highest on days 7 through 15 following thermal injury. Further research is needed to study the mechanisms of endothelial damage in patients with thermal burns.

Keywords: burns, endothelial dysfunction, hemostasis, hypocoagulation, systemic inflammatory response

Author contribution: Morrison W - design of the experiment, data analysis, manuscript revision; Bozhedomov AYu — data collection and statistical analysis, manuscript draft.

Compliance with ethical standards: the study was approved by the Ethics Committee of Saratov State Medical University (Protocol No. 5 dated May 27, 2010); the patients gave informed consent to participate in the study and to disclose information about their medical condition and treatment on the Internet for the sake of science.

Correspondence should be addressed: Alexey Yu. Bozhedomov

Ostrovityanova 1, Moscow, 117997; alecso_84@mail.ru

Received: 28.12.2018 Accepted: 26.03.2019 Published online: 07.04.2019

DOI: $10.24075 /$ brsmu.2019.021

\section{ДИНАМИКА ПОКАЗАТЕЛЕЙ ГЕМОСТАЗА И ЭНДОТЕЛИАЛЬНОЙ ДИСФУНКЦИИ ПРИ ТЕРМИЧЕСКОЙ ТРАВМЕ}

В. В. Моррисон ${ }^{1}$, А. Ю. Божедомов ${ }^{2}$

' Саратовский государственный медицинский университет имени В. И. Разумовского, Саратов, Россия

2 Российский национальный исследовательский медицинский университет имени Н. И. Пирогова, Москва, Россия

Ожоги остаются причиной смертности сотен тысяч людей. Целью работы было изучить динамику изменений показателей системной воспалительной реакции, эндотелиальной дисфункции и нарушений гемостаза у пострадавших от ожогов. У 51 пациента в возрасте 16-80 лет с термическими ожогами

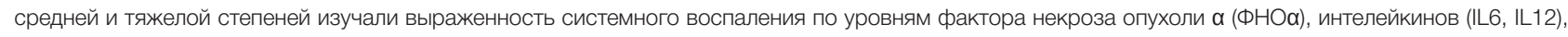
С-реактивного протеина, моноцитарного хемоаттрактантного протеина-1 (МСР-1). Состояние гемостаза оценивали на основании коагулометрических исследований (активированное парциальное тромбопластиновое время (АПТВ), протромбиновый индекс (ПТИ), протромбиновое время (ПТВ) и др.), количества тромбоцитов; дисфункцию эндотелия - по уровням васкулоэндотелиального ростового фактора (VEGF), общего эндотелина (ЭT), циркулирующих эндотелиальных клеток. Показатели изучали в динамике на 1-45-е сутки с момента получения травмы. Наибольшую выраженность

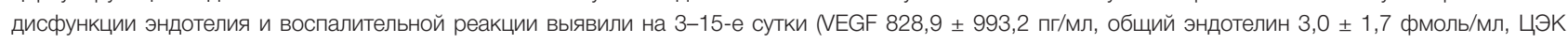
6,4 \pm 6,0 • 104/л, IL6 264,4 \pm 131,2 пг/мл, ФHOa 41,4 \pm 111,9 пг/мл, С-реактивный белок 128,3 \pm 52,4 нмоль/мл). В этот же период было отмечено

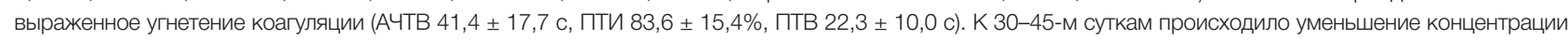

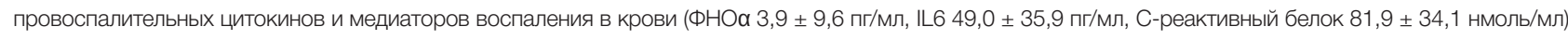

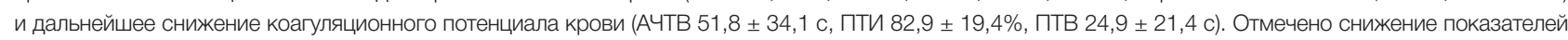
гемокоагуляции. Показано, что происходит повреждение эндотелия сосудов как продуктами, попадающими из ожоговых ран, так и медиаторами воспалительной реакции. Риск тромбоэмболических и геморрагических осложнений максимален с 7-х по 15-е сутки ожоговой болезни. Требуются дальнейшие более детальные исследования механизмов повреждения эндотелия при ожогах.

Ключевые слова: ожоги, эндотелиальная диссункция, гемостаз, гипокоагуляция, системная воспалительная реакция

Информация о вкладе авторов: Моррисон В. В. — планирование эксперимента, анализ материала, редактирование статьи; Божедомов А. Ю. - сбор и анализ материала, статистическая обработка, написание текста статьи.

Соблюдение этических стандартов: исследование одобрено этическим комитетом Саратовского государственного медицинского университета им. В. И. Разумовского (протокол № 5 от 27 мая 2010 г.); пациенты, включенные в исследование, подписали согласие на публикацию и размещение в интернете информации о характере заболевания, проведенном лечении и его результатах с научной и образовательной целями.

$\triangle$ Для корреспонденции: Алексей Юрьевич Божедомов ул. Островитянова, д. 1, г. Москва, 117997; alecso_84@mail.ru

Статья получена: 28.12.2018 Статья принята к печати: 26.03.2019 Опубликована онлайн: 07.04.2019

DOI: $10.24075 /$ vrgmu.2019.021 
There is increasing evidence of a complex interplay between systemic inflammation, hemostasis and endothelial dysfunction observed in severe pathology [1]. Burn injuries are not an exception, especially when the burn size exceeds $10 \%$ of total body surface area. The primary cause of death in burned patients is multiple organ dysfunction syndrome (MODS) resulting from the inability of adaptation mechanisms to cope with severe trauma-induced stress, hypermetabolism and damage done by the toxic products of tissue destruction [2, 3]. Although the pathophysiology of burn injury is relatively well studied, burns still kill thousands of people each year, posing a significant economic burden.

MODS is driven by a cytokine storm resulting from hyperproduction of cytokines. This phenomenon leads to systemic endothelial damage, disrupts microcirculation and transcapillary exchange $[4,5]$. Therefore, endothelial dysfunction should be regarded as an important MODS manifestation and its contributor [6].

This study aimed to investigate the dynamics of hemostasis, systemic inflammatory response and endothelial dysfunction markers in patients with thermal injury.

\section{METHODS}

This prospective study was conducted in 51 patients (37 males and 14 females) aged 16 to 80 years undergoing treatment at Saratov Center of Thermal Injuries. The mean age of the participants was $40.5 \pm 36.2$ years $(\mathrm{M} \pm \sigma)$. The study included patients with fire or scald burns with a prognostic index over 30 calculated as an area of small first to third degree burns +3 areas of deep third to fourth degree burns (the index was proposed by $\mathrm{G}$. Frank in 1960). On average, the Frank index was $80.1 \pm 63.2(M \pm \sigma)$. The following exclusion criteria were applied: age under 16 and over 80 years (age significantly affects the organism's response to thermal injury); electrical or inhalation injury (the lesion size did not correlate with the severity of the condition); pregnancy; clinically uncompensated comorbidities at the time of admission. The death rate among the patients was $37 \%$.

The patients were brought to the hospital within $1 \mathrm{~h}$ to 3 days after sustaining injury. Their serum samples were collected and assayed for endothelial dysfunction biomarkers, including vascular endothelial growth factor (VEGF) (reagents by Biosource, EuropeS.A; Belgium), monocyte chemoattractant protein 1 (MCP-1) (reagents by Vector Best; Novosibirsk) and total endothelin (reagents by BiomedicaGruppe; Austria). ELISA assays were performed in a StatFax 2100 microplate reader (Awareness Technology Inc.; USA). We also measured the levels of IL6, IL12 and tumor necrosis factor a (TNFa) using the kits by Biosource, EuropeS.A, Belgium. Circulating endothelial cells (CEC) were counted by phase-contrast microscopy using a method proposed by J. Hladovec and modified by N. Petrischev [7]. The severity of inflammation was inferred from C-reactive protein (CRP) levels measured by solid-phase enzyme immunoassay (Vector Best; Novosibirsk). Hemostasis dynamics were assessed based on fibrinogen levels, the prothrombin time $(\mathrm{PT})$, the prothrombin index $(\mathrm{PI})$, the activated partial thromboplastin time (APTT), and platelet count. Some factors of endothelial dysfunction are described in Table 1.

Fasting blood samples were collected from central or peripheral veins at $8 \mathrm{am}$. The tests were performed on days $1,3,5,15,30$, and 45 following the injury. The number of patients fluctuated at different stages of the study because some of them were admitted to the hospital later than 1 day after the injury, some were discharged when their condition had improved, and some died. All of them received treatment according to the standard procedures for burn care adopted in the hospital.

Blood samples of 20 healthy volunteers were used as a control. Of those individuals, 12 were men and 8 women with a mean age of $37.5 \pm 18.4$ years.

\section{Statistical analysis}

The obtained data were processed in Statistica v10.0 (StatSoft; USA) and expressed as a mean and a standard deviation from the mean $(M \pm \sigma)$. The groups were compared using Student's t-test, which is usually applied to the samples with normal distribution. Differences were considered significant at $p \leq 0.05$, a standard value used in medical and biological research. The distribution type was determined by the Shapiro-Wilk test. The distribution in the sample was considered normal at $p>0.05$.

\section{RESULTS}

Coagulation parameters were quite stable during the entire post-injury period. Over time, though, PI started to decline gradually, whereas PT and APTT started to grow. This may have been caused by the depletion of protein reserve, infusion therapy and antithrombotic agents.

The levels of fibrinogen, one of the acute-phase proteins, peaked on day $7(5.6 \pm 2.2 \mathrm{~g} / \mathrm{L})$ during the acute autointoxication phase.

The dynamics of platelet levels were different. The highest platelet count was observed on days 15 through 30 (555.3 \pm $\left.344.9 \cdot 10^{\circ} / \mathrm{L}\right)$. Platelets were also significantly elevated in the survivors, in contrast to non-survivors.

The most pronounced hemostatic changes were seen during the acute autointoxication phase or sepsis (days 7 through 15). That period was marked by hypercoagulation and an increasing risk of thromboembolic complications (Table 2).

The highest concentrations of proinflammatory cytokines and acute-phase mediators (TNFa, CRP, IL6) were observed on days 3 through 7 , corresponding to the acute autointoxication phase of the burn injury (Table 3).

In contrast, the levels of IL12, which stimulates proliferation and differentiation of lymphocytes, reached their peak in the recovering patients $(131.3 \pm 70.7 \mathrm{pg} / \mathrm{mL})$ and demonstrated the lowest values in the acute autointoxication phase or sepsis $(35.7 \pm 22.9 \mathrm{pg} / \mathrm{mL})$.

Table 1. Markers of endothelial dysfunction

\begin{tabular}{|c|l|}
\hline Name & \multicolumn{1}{c|}{ Description } \\
\hline VEGF & $\begin{array}{l}\text { A potent angiogenic and mitogenic factor; its levels rise in response to hypoxia or cancer, during wound healing or gestosis. It is secreted } \\
\text { by endothelial cells, macrophages, fibroblasts, and some other cells [8] }\end{array}$ \\
\hline CEC & $\begin{array}{l}\text { CEC levels rise in response to vascular endothelial damage, increased necrosis of endothelial cells, hypoxia, sepsis, sever intoxication, } \\
\text { atherosclerosis, other cardiovascular diseases, and gestosis [9] }\end{array}$ \\
\hline Endothelin & $\begin{array}{l}\text { ET is involved in the local regulation of vascular tone. It is an antagonist of endothelium-derived relaxing factor NO and an indirect indicator } \\
\text { of its activity. Contributes to the progression of cardiovascular pathology and is involved into blood flow centralization during massive } \\
\text { blood loss. ET is secreted by endothelial cells [10, 11] }\end{array}$ \\
\hline
\end{tabular}


Monocyte chemoattractant protein 1 (chemokine) is secreted by a variety of cells, including fibroblasts, endothelial cells and macrophages and recruits monocytes to an inflammation site. MCP-1 had two peaks: during acute autointoxication (381.7 \pm $560.49 \mathrm{pg} / \mathrm{mL}$ ) and during recovery (514.7 $\pm 740.9 \mathrm{pg} / \mathrm{mL})$. The second peak was more pronounced.

The highest concentrations of endothelial dysfunction markers were observed on days 3-7. On day 7, VEGF rose 30 -fold, in comparison with the controls $(828.9 \pm 993.2 \mathrm{pg} / \mathrm{mL})$. That period was also marked by an elevated blood plasma count of desquamated endothelial cells (as high as $5.9 \pm 6.0 \cdot 10^{9} / \mathrm{L}$; Table 4). This suggests acute hypoxia of the endothelium, its intense desquamation and increased apoptosis or necrosis.

The concentrations of cytokines and endothelial dysfunction markers were compared in the patients with normal coagulation and coagulopathy. Hypocoagulation was inferred from APTT > $35 \mathrm{~s}$ and $\mathrm{PI}<85 \%$ (Tables 5, 6). Decreased coagulation cooccurred with significantly increased levels of acute-phase proteins (CRP, IL6, TNFa), VEGF, CEC, and low (in comparison with patients with normal coagulation) IL12, MCP-1, and endothelin.

\section{DISCUSSION}

We have found that a rise in the levels of proinflammatory cytokines co-occurs with coagulopathy and an increase in endothelial dysfunction markers. Previously, we studied cytokine concentrations in patients with thermal burn injuries of different severity and noticed that endothelial dysfunction markers followed a phase pattern. Those markers rose significantly in patients with mild and moderate burns, peaked in patients with severe but not fatal burn injuries, and declined in the end stage of MODS in non-survivors [12]. It is known that endothelial dysfunction triggers activation of prothrombotic mechanisms and increases coagulability, promoting disseminated intravascular blood coagulation. Compromised vessel wall integrity results in the hyperproduction of endothelin, which stimulates activation of all phases of hemostasis; endothelin levels rise in patients with severe trauma $[13,14]$.

Our findings suggest that the levels of proinflammatory cytokines and endothelial dysfunction factors in severe burn injuries are inversely proportional.

Table 2. Hemostasis dynamics in patients with burn injuries, $M \pm \sigma$

\begin{tabular}{|c|c|c|c|c|c|c|c|}
\hline Parameter & $\begin{array}{l}\text { Day } 1 \\
n=50\end{array}$ & $\begin{array}{l}\text { Day } 3 \\
n=51\end{array}$ & $\begin{array}{l}\text { Day } 7 \\
n=49\end{array}$ & $\begin{array}{l}\text { Day } 15 \\
n=40\end{array}$ & $\begin{array}{l}\text { Day } 30 \\
n=36\end{array}$ & $\begin{array}{c}\text { Day } 45 \\
n=19\end{array}$ & $\begin{array}{c}\text { Controls } \\
n=20\end{array}$ \\
\hline APTT, s & $\begin{array}{l}39.6 \pm 25.4 \\
\left(p_{\mathrm{k}}=0.02\right)^{\mathrm{k}}\end{array}$ & $\begin{array}{c}41.4 \pm 17.7 \\
\left(p=0.5 ; p_{\mathrm{K}}=0.05\right)\end{array}$ & $\begin{array}{c}41.9 \pm 25.3 \\
\left(p=0.88 ; p_{\mathrm{k}}=0.03\right)^{\mathrm{k}}\end{array}$ & $\begin{array}{c}40.2 \pm 27.0 \\
\left(p=0.48 ; p_{\kappa}=0.27\right)\end{array}$ & $\begin{array}{c}50.4 \pm 31.4 \\
\left(p=0.001 ; p_{\mathrm{K}}=0.03\right)^{\star_{\mathrm{K}}}\end{array}$ & $\begin{array}{c}51.8 \pm 34.1 \\
\left(p=0.80 ; p_{\mathrm{k}}=0.04\right)^{\mathrm{K}}\end{array}$ & $26.2 \pm 2.8$ \\
\hline $\mathrm{Pl}, \%$ & $\begin{array}{c}90.9 \pm 14.1 \\
\left(p_{\mathrm{K}}=0.25\right)\end{array}$ & $\begin{array}{c}86.5 \pm 13.3 \\
\left(p=0.03 ; p_{\kappa}=0.02\right)^{\star \kappa}\end{array}$ & $\begin{array}{c}83.6 \pm 15.4 \\
\left(p=0.09 ; p_{\mathrm{k}}=0.01\right)^{\mathrm{k}}\end{array}$ & $\begin{array}{c}83.1 \pm 16.5 \\
\left(p=0.86 ; p_{\mathrm{k}}=0.01\right)^{\mathrm{k}}\end{array}$ & $\begin{array}{c}82.3 \pm 17.5 \\
\left(p=0.07 ; p_{\mathrm{k}}=0.01\right)^{\mathrm{\kappa}}\end{array}$ & $\begin{array}{c}82.9 \pm 19.4 \\
\left(p=0.82 ; p_{\mathrm{k}}=0.03\right)^{\mathrm{k}}\end{array}$ & $101.1 \pm 6.3$ \\
\hline PT, s & $\begin{array}{l}19.5 \pm 6.3 \\
\left(p_{\mathrm{K}}=0.04\right)^{\mathrm{K}}\end{array}$ & $\begin{array}{c}22.2 \pm 17.6 \\
\left(p=0.22 ; p_{\mathrm{K}}=0.04\right)^{\mathrm{k}}\end{array}$ & $\begin{array}{c}22.3 \pm 10.0 \\
\left.p=0.82 ; p_{\mathrm{K}}=0.03\right)\end{array}$ & $\begin{array}{c}21.8 \pm 8.0 \\
\left(p=0.96 ; p_{\mathrm{K}}=0.01\right)^{\mathrm{K}}\end{array}$ & $\begin{aligned} & 24.9 \pm 21.4 \\
&\left(p=0.11 ; p_{\mathrm{k}}=0.04\right)^{\mathrm{K}}\end{aligned}$ & $\begin{array}{c}22.9 \pm 13.5 \\
\left(p=0.52 ; p_{\mathrm{k}}=0.04\right)^{\mathrm{\kappa}}\end{array}$ & $12.6 \pm 0.9$ \\
\hline $\begin{array}{c}\text { Fibrinogen, } \\
\text { g/L }\end{array}$ & $\begin{array}{c}3.4 \pm 1.4 \\
\left(p_{\mathrm{K}}=0.11\right)\end{array}$ & $\begin{array}{c}5.2 \pm 2.0 \\
\left(p=0.001 ; p_{\mathrm{K}}=0.04\right)^{\star_{\mathrm{K}}}\end{array}$ & $\begin{array}{c}5.6 \pm 2.2 \\
\left(p=0.43 ; p_{\mathrm{K}}=0.001\right)^{\mathrm{K}}\end{array}$ & $\begin{array}{c}5.0 \pm 2.1 \\
\left(p=0.06 ; p_{\mathrm{K}}=0.001\right)^{\mathrm{K}}\end{array}$ & $\begin{array}{c}4.7 \pm 1.8 \\
\left(p=0.22 ; p_{\mathrm{K}}=0.001\right)^{\mathrm{K}}\end{array}$ & $\begin{array}{c}4.2 \pm 1.7 \\
\left(p=0.03 ; p_{\mathrm{K}}=0.05\right)\end{array}$ & $3.3 \pm 0.69$ \\
\hline $\begin{array}{l}\text { Platelets, } \\
\qquad 10^{9} / \mathrm{L}\end{array}$ & $\begin{array}{c}319.6 \pm 197.0 \\
\left(p_{k}=0.27\right)\end{array}$ & $\begin{array}{c}209 \pm 122.9 \\
\left(p=0.001 ; p_{k}=0.47\right)^{\star}\end{array}$ & $\begin{array}{c}316.0 \pm 214.6 \\
\left(p=0.001 ; p_{k}=0.09\right)^{\star}\end{array}$ & $\begin{array}{c}555.3 \pm 344.9 \\
\left(p=0.001 ; p_{\mathrm{k}}=0.04\right)^{\star_{\mathrm{K}}}\end{array}$ & $\begin{array}{c}467.8 \pm 237.9 \\
\left(p=0.04 ; p_{\kappa}=0.03\right)^{\star_{\kappa}}\end{array}$ & $\begin{array}{c}454.3 \pm 294.4 \\
\left(p=0.03 ; p_{k}=0.03\right)^{\mathrm{K}}\end{array}$ & $230.4 \pm 224.9$ \\
\hline
\end{tabular}

Note: $p$ - the specified and the previous stages of the study are compared; ${ }^{*}$ — the differences between the specified and the previous stages of the study are significant $(p<0.05) ; p_{k}$ — the patients compared to the controls at the specified stage of the study; ${ }^{k}$ - the differences between the patients and the controls are significant $(p<0.05)$.

Table 3. Cytokine dynamics in patients with burn injuries, $M \pm \sigma$

\begin{tabular}{|c|c|c|c|c|c|c|c|}
\hline Parameter & $\begin{array}{l}\text { Day } 1 \\
n=50\end{array}$ & $\begin{array}{l}\text { Day } 3 \\
n=51\end{array}$ & $\begin{array}{l}\text { Day } 7 \\
n=49\end{array}$ & $\begin{array}{l}\text { Day } 15 \\
n=40\end{array}$ & $\begin{array}{c}\text { Day } 30 \\
n=36\end{array}$ & $\begin{array}{c}\text { Day } 45 \\
n=19\end{array}$ & $\begin{array}{c}\text { Controls } \\
n=20\end{array}$ \\
\hline TNF $\alpha, p g / m L$ & $\begin{array}{l}42.3 \pm 46.6 \\
\left(p_{\mathrm{k}}=0.04\right)^{\mathrm{k}}\end{array}$ & $\begin{array}{c}32.2 \pm 99.3 \\
\left(p=0.79 ; p_{\mathrm{k}}=0.03\right)^{\mathrm{k}}\end{array}$ & $\begin{array}{c}41.4 \pm 111.9 \\
\left(p=0.85 ; p_{\mathrm{K}}=0.02\right)^{\mathrm{K}}\end{array}$ & $\begin{array}{c}17.8 \pm 47.9 \\
\left(p=0.45 ; p_{\mathrm{k}}=0.03\right)^{\mathrm{k}}\end{array}$ & $\begin{array}{c}3.9 \pm 9.6 \\
\left(p=0.26 ; p_{\mathrm{K}}=0.003\right)^{\mathrm{K}}\end{array}$ & $\begin{array}{c}8.2 \pm 12.1 \\
\left(p=0.30 ; p_{\mathrm{k}}=0.01\right)^{\mathrm{K}}\end{array}$ & $0.2 \pm 0.3$ \\
\hline $\begin{array}{c}\mathrm{IL} 6, \\
\mathrm{pg} / \mathrm{mL}\end{array}$ & $\begin{array}{c}114.1 \pm 172.8 \\
\left(p_{\mathrm{K}}=0.008\right)^{\mathrm{k}}\end{array}$ & $\begin{array}{c}264.4 \pm 131.2 \\
\left(p=0.05 ; p_{\mathrm{K}}=0.001\right)^{\mathrm{k}}\end{array}$ & $\begin{array}{c}203.8 \pm 180.9 \\
\left(p=0.39 ; p_{\mathrm{K}}=0.001\right)^{\mathrm{k}}\end{array}$ & $\begin{array}{c}67.8 \pm 63.4 \\
\left(p=0.07 ; p_{\mathrm{K}}=0.001\right)^{\mathrm{K}}\end{array}$ & $\begin{array}{c}49.0 \pm 35.9 \\
\left(p=0.51 ; p_{\kappa}=0.001\right)^{\kappa}\end{array}$ & $\begin{array}{c}68.9 \pm 66.3 \\
\left(p=0.51 ; p_{\mathrm{K}}=0.001\right)^{\mathrm{K}}\end{array}$ & $4.2 \pm 3.1$ \\
\hline $\begin{array}{l}\mathrm{IL} 12, \\
\mathrm{pg} / \mathrm{mL}\end{array}$ & $\begin{array}{l}46.9 \pm 53.8 \\
\left(p_{\mathrm{k}}=0.001\right)^{\mathrm{k}}\end{array}$ & $\begin{array}{c}39.4 \pm 32.9 \\
\left(p=0.63 ; p_{\mathrm{k}}=0.001\right)^{\mathrm{k}}\end{array}$ & $\begin{array}{c}35.7 \pm 22.9 \\
\left(p=0.45 ; p_{\mathrm{K}}=0.001\right)^{\mathrm{K}}\end{array}$ & $\begin{array}{c}54.9 \pm 41.0 \\
\left(p=0.03 ; p_{\mathrm{K}}=0.001\right)^{\star_{\mathrm{K}}}\end{array}$ & $\begin{array}{c}81.3 \pm 50.0 \\
\left(p=0.06 ; p_{k}=0.001\right)^{\mathrm{K}}\end{array}$ & $\begin{array}{c}131.3 \pm 70.7 \\
\left(p=0.02 ; p_{\mathrm{K}}=0.001\right)^{\mathrm{k} *}\end{array}$ & $3.1 \pm 3.2$ \\
\hline $\begin{array}{l}\text { C-reactive protein, } \\
\mathrm{nmol} / \mathrm{mL}\end{array}$ & $\begin{array}{l}43.2 \pm 46.6 \\
\left(p_{\mathrm{k}}=0.001\right)^{\mathrm{\kappa}}\end{array}$ & $\begin{array}{c}128.1 \pm 49.6 \\
\left(p=0.001 ; p_{\mathrm{K}}=0.001\right)^{\star \kappa}\end{array}$ & $\begin{array}{c}128.3 \pm 52.4 \\
\left(p=0.93 ; p_{\mathrm{K}}=0.001\right)^{\mathrm{K}}\end{array}$ & $\begin{array}{c}85.1 \pm 41.7 \\
\left(p=0.001 ; p_{\mathrm{K}}=0.001\right)^{\star \kappa}\end{array}$ & $\begin{array}{c}81.9 \pm 34.1 \\
\left(p=0.79 ; p_{\mathrm{K}}=0.001\right)^{\mathrm{K}}\end{array}$ & $\begin{array}{c}110.3 \pm 57.7 \\
\left(p=0.08 ; p_{\mathrm{K}}=0.001\right)^{\mathrm{K}}\end{array}$ & $1.2 \pm 1.1$ \\
\hline $\mathrm{MCP}-1, \mathrm{pg} / \mathrm{ml}$ & $\begin{array}{c}198.9 \pm 191.7 \\
\left(p_{\mathrm{K}}=0.001\right)^{\mathrm{K}}\end{array}$ & $\begin{array}{c}319.1 \pm 238.3 \\
\left(p=0.04 ; p_{\mathrm{K}}=0.001\right)^{\star{ }_{\mathrm{K}}}\end{array}$ & $\begin{array}{c}381.7 \pm 560.49 \\
\left(p=0.5 ; p_{\mathrm{K}}=0.009\right)^{\mathrm{\kappa}}\end{array}$ & $\begin{array}{c}229.9 \pm 210.3 \\
\left(p=0.11 ; p_{\mathrm{K}}=0.001\right)^{\mathrm{K}}\end{array}$ & $\begin{array}{c}287.1 \pm 231.9 \\
\left(p=0.29 ; p_{\mathrm{K}}=0.001\right)^{\mathrm{K}}\end{array}$ & $\begin{array}{c}514.7 \pm 740.9 \\
\left(p=0.11 ; p_{\mathrm{K}}=0.009\right)^{\mathrm{K}}\end{array}$ & $44.1 \pm 36.5$ \\
\hline
\end{tabular}

Note: $p$ - the specified and the previous stages of the study are compared; ${ }^{*}$ — the differences between the specified and the previous stages of the study are significant $(p<0.05) ; p_{k}$ — the patients compared to the controls at the specified stage of the study; ${ }^{k}$ — the differences between the patients and the controls are significant $(p<0.05)$

Table 4. Dynamics of endothelial dysfunction markers in patients with burn injuries, $M \pm \sigma$

\begin{tabular}{|c|c|c|c|c|c|c|c|}
\hline Parameter & $\begin{array}{l}\text { Day } 1 \\
n=50\end{array}$ & $\begin{array}{l}\text { Day } 3 \\
n=51\end{array}$ & $\begin{array}{l}\text { Day } 7 \\
n=49\end{array}$ & $\begin{array}{l}\text { Day } 15 \\
n=40\end{array}$ & $\begin{array}{c}\text { Day } 30 \\
n=36\end{array}$ & $\begin{array}{c}\text { Day } 45 \\
n=19\end{array}$ & $\begin{array}{c}\text { Controls } \\
n=20\end{array}$ \\
\hline $\begin{array}{l}\text { VEGF, } \\
\mathrm{pg} / \mathrm{mL}\end{array}$ & $\begin{array}{c}546.4 \pm 692.8 \\
\left(p_{k}=0.02\right)^{k}\end{array}$ & $\begin{array}{c}476.4 \pm 626.9 \\
\left(p=0.68 ; p_{\mathrm{K}}=0.003\right)^{\mathrm{K}}\end{array}$ & $\begin{array}{c}828.9 \pm 993.2 \\
\left(p=0.06 ; p_{\mathrm{K}}=0.001\right)^{\mathrm{k}}\end{array}$ & $\begin{array}{c}544.4 \pm 570.9 \\
\left(p=0.11 ; p_{\mathrm{K}}=0.001\right)^{\mathrm{\kappa}}\end{array}$ & $\begin{array}{c}505.6 \pm 551.1 \\
\left(p=0.77 ; p_{\mathrm{k}}=0.001\right)^{\mathrm{K}}\end{array}$ & $\begin{array}{c}958.1 \pm 1025.6 \\
\left(p=0.04 ; p_{\mathrm{K}}=0.001\right)^{\star \star}\end{array}$ & $28.7 \pm 15.7$ \\
\hline $\begin{array}{l}\text { Endothelin, } \\
\mathrm{fmol} / \mathrm{mL}\end{array}$ & $\begin{array}{c}3.2 \pm 3.2 \\
\left(p_{\mathrm{K}}=0.001\right)^{\mathrm{K}}\end{array}$ & $\begin{array}{c}3.0 \pm 1.7 \\
\left(p=0.88 ; p_{\mathrm{K}}=0.001\right)^{\mathrm{K}}\end{array}$ & $\begin{array}{c}2.97 \pm 1.32 \\
\left(p=0.76 ; p_{\mathrm{K}}=0.001\right)^{\mathrm{K}}\end{array}$ & $\begin{array}{c}2.4 \pm 1.2 \\
\left(p=0.11 ; p_{\mathrm{K}}=0.001\right)^{\mathrm{K}}\end{array}$ & $\begin{array}{c}2.3 \pm 1.1 \\
\left(p=0.71 ; p_{\mathrm{K}}=0.001\right)^{\mathrm{K}}\end{array}$ & $\begin{array}{c}2.4 \pm 1.3 \\
\left(p=0.93 ; p_{\mathrm{K}}=0.001\right)^{\mathrm{K}}\end{array}$ & $0.42 \pm 0.4$ \\
\hline CEC, $10^{4} / \mathrm{L}$ & $\begin{array}{l}3.3 \pm 2.5 \\
\left(p_{\kappa}=0.48\right)\end{array}$ & $\begin{array}{c}4.7 \pm 3.3 \\
\left(p=0.09 ; p_{\mathrm{k}}=0.05\right)\end{array}$ & $\begin{array}{c}5.9 \pm 4.9 \\
\left(p=0.28 ; p_{\mathrm{K}}=0.03\right)^{\mathrm{K}}\end{array}$ & $\begin{array}{c}6.4 \pm 6.0 \\
\left(p=0.62 ; p_{\mathrm{k}}=0.04\right)^{\mathrm{\kappa}}\end{array}$ & $\begin{array}{c}3.7 \pm 3.1 \\
\left(p=0.02 ; p_{k}=0.29\right)^{\star}\end{array}$ & $\begin{array}{c}2.9 \pm 1.6 \\
\left(p=0.33 ; p_{\mathrm{K}}=0.78\right)\end{array}$ & $2.8 \pm 1.9$ \\
\hline
\end{tabular}

Note: $p$ - the specified and the previous stages of the study are compared; ${ }^{*}$ — the differences between the specified and the previous stages of the study are significant $(p<0.05) ; p_{k}$ - the patients compared to the controls at the specified stage of the study; ${ }^{k}$ - the differences between the patients and the controls are significant $(p<0.05)$. 
Table 5. Differences in the values of blood coagulation parameters in burn patients with normal coagulation and coagulopathy, $\mathrm{M} \pm 0$

\begin{tabular}{|c|c|c|c|c|c|}
\hline Group & APTT, s & PT, s & PI, \% & Fibrinogen, g/L & Platelets, $\bullet 10^{\circ} / \mathrm{L}$ \\
\hline Normal coagulation & $31.3 \pm 2.9$ & $19.0 \pm 3.6$ & $89.1 \pm 13.4$ & $4.2 \pm 1.2$ & $391.5 \pm 215.4$ \\
\hline Hypocoagulation & $54.5 \pm 27.9(p=0.001)^{\star}$ & $20.9 \pm 5.0(p=0.01)^{\star}$ & $81.8 \pm 12.8(p=0.001)^{\star}$ & $4.9 \pm 1.4(p=0.001)^{\star}$ & $391.2 \pm 216.9(p=0.99)$ \\
\hline
\end{tabular}

Note: * - the difference between the two groups is significant $(p<0.05)$.

Table 6. Differences in the levels of cytokines and endothelial dysfunction markers in burn patients with normal coagulation and coagulopathy, $\mathrm{M} \pm \sigma$

\begin{tabular}{|c|c|c|c|c|c|c|c|c|}
\hline Group & $\mathrm{CRP}, \mathrm{nmol} / \mathrm{mL}$ & $\mathrm{IL6}, \mathrm{pg} / \mathrm{mL}$ & $\mathrm{TNF}, \mathrm{pg} / \mathrm{mL}$ & $\mathrm{IL} 12, \mathrm{pg} / \mathrm{mL}$ & $\mathrm{MCP}-1, \mathrm{pg} / \mathrm{mL}$ & $\mathrm{VEGF}, \mathrm{pg} / \mathrm{mL}$ & $\mathrm{ET}, \mathrm{fmol} / \mathrm{mL}$ & $\mathrm{CEC}, \cdot 10^{4} / \mathrm{L}$ \\
\hline Normal coagulation & $75.0 \pm 49.1$ & $50.3 \pm 63.9$ & $9.1 \pm 28.5$ & $68.6 \pm 55.6$ & $308.2 \pm 231.6$ & $578.5 \pm 523.9$ & $2.96 \pm 2.7$ & $4.4 \pm 3.6$ \\
\hline \multirow{2}{*}{ Hypocoagulation } & $97.4 \pm 47.7$ & $\begin{array}{c}145.2 \pm 138.3 \\
(p=0.04)^{*}\end{array}$ & $\begin{array}{c}45.5 \pm 114.3 \\
(p=0.35)\end{array}$ & $\begin{array}{c}48.3 \pm 46.4 \\
(p=0.10)\end{array}$ & $\begin{array}{c}252.8 \pm 238.2 \\
(p=0.08)\end{array}$ & $\begin{array}{c}712.3 \pm 745.0 \\
(p=0.26)\end{array}$ & $\begin{array}{c}2.41 \pm 1.3 \\
(p=0.35)\end{array}$ & $\begin{array}{c}5.0 \pm 4.9 \\
(p=0.21)\end{array}$ \\
& $(p=0.37)$ \\
\hline
\end{tabular}

Note: * - the difference between the two groups is significant $(p<0.05)$.

Cytokines stimulate production of free radicals, Iysosomal enzymes and cationic proteins by phagocytes and cytotoxic lymphocytes and activate humoral factors (complement components, properdin, kinins), causing endothelial dysfunction. In response, endothelial cells secrete autocrine and paracrine regulatory factors, such as VEGF and endothelin. When activated by proinflammatory cytokines, endothelial cells increase expression of adhesion molecules and launch degranulation of Weibel-Palade bodies (vesicles inside a vascular endothelial cells), thereby destabilizing the endothelial lining, reducing resistance to blood clotting and increasing permeability of blood vessels [15]. Damage to the vascular endothelium results in excessive cell desquamation. Growing VEGF concentrations aim to regulate neoangiogenesis in response to the endothelial damage induced by hypoxia in the acute autointoxication phase of burn injury and to promote tissue regeneration in the recovery period (days 30-45) [13]. Most likely, the function of the inducible NO synthase is also altered significantly, because there is evidence that blood NO metabolites decline following thermal injury [16]. Therefore, a rise in endothelin levels could be compensatory. Also, there are reports that this factor participates in blood flow centralization in other severe pathologies [10].

\section{References}

1. Dumnicka P, Maduzia D, Ceranowicz P, et al. The Interplay between Inflammation, Coagulation and Endothelial Injury in the Early Phase of Acute Pancreatitis: Clinical Implications. Int $\mathrm{J} \mathrm{Mol}$ Sci. 2017; 18 (2): E354. DOI: 10.3390/ijms18020354. PubMed PMID: 28208708.

2. Alekseev AA, Ushakova TA, Krutikov MG, Bobrovnikov AYe. Markery sepsisa $v$ diagnostike adaptivnogo vospalenija pri ozhogovoj travme. Lechenie i profilaktika. 2015; 2 (14): 84-91. Russian.

3. Ushakova TA. Adaptacija k ozhogovoj travme: problemy i perspektivy. Kombustiologija. 2009; 39. Dostupno po ssylke: www.combustiolog.ru (data obrashhenija 23.06.2018). Russian.

4. Chousterman BG, Swirski FK, Weber GF. Cytokine storm and sepsis disease pathogenesis. Semin Immunopathol. 2017; 39 (5): 517-28.

5. Ince C, Mayeux PR, Nguyen T, et al. The endothelium in sepsis. Shock. 2016; 45 (3): 259-70.

6. Abdel-Hafez NM, Saleh Hassan Y, El-Metwally TH. A study on biomarkers, cytokines, and growth factors in children with burn injuries. Ann Burns Fire Disasters. 2007; 20 (2): 89-100.

7. Petrishhev NN, Berkovich OA, Vlasov TD i dr. Diagnosticheskaja cennost' opredelenija deskvamirovannyh jendotelial'nyh kletok v krovi. Klinicheskaja laboratornaja diagnostika. 2001; (1): 50-2. Russian.

8. Gavrilenko TI, Ryzhkova NA, Parhomenko AN. Sosudistyj jendotelial'nyj faktor rosta $v$ klinike vnutrennih zabolevanij i ego
Growing concentrations of those damaging factors promote endothelial dysfunction and energy deficit, impair protein synthesis and contribute to the inhibition of procoagulant properties of proteins, eventually leading to hypercoagulation. The syndrome of disseminated intravascular blood coagulation developed by most patients with severe burns leads to a reduction in the plasma levels of coagulation factors. Besides, a deficit of amino acids is observed that are increasingly utilized to maintain tissue regeneration.

\section{CONCLUSIONS}

Our findings demonstrate that thermal burns affect the structure and function of the vascular endothelium. Those changes are a manifestation of the systemic inflammatory response accompanied by the presence of highly specific markers of endothelial dysfunction in the blood. In patients with severe burns, the correlation between the levels of proinflammatory cytokines and functional parameters of hemostasis is inversely proportional. Further research is needed to investigate the relationship between hemostatic impairment and endothelial dysfunction in patients with severe trauma in general and burn injury in particular. patogeneticheskoe znachenie. Ukraïns'kij kardiologichnij zhurnal. 2011; (4): 87-95. Russian.

9. Erdbruegger U, Haubitez M, Woywodt A. Circulating endothelial cells: a novel marker of endothelial damage. Clinica Chimica Acta. 2006; (373): 17-26.

10. Dremina NN, Shurygin MG, Shurygina IA. Jendoteliny v norme i patologii. Mezhdunarodnyj zhurnal prikladnyh i fundamental'nyh issledovanij. 2016; (10): 210-14. Russian.

11. Yanagisawa M, Masaki T. Molecular biology and biochemistry of the endothelins. Trends Pharmacol Sci. 1989; 10 (9): 374-8.

12. Morrison VV, Bozhedomov AYu. Disfunkcija jendotelija pri sindrome poliorgannoj nedostatochnosti u bol'nyh s termicheskoj travmoj. Regionarnoe krovoobrashhenie i mikrocirkuljacija. 2013; 2 (46): 43-8. Russian.

13. Iba T, Kidokoro A, Fukunaga M, et al. Association between the severity of sepsis and the changes in hemostatic molecular markers and vascular endothelial damage markers. Shock. 2005; 23 (1): 25-9.

14. Firsov SA, Matveev RP. Jendotelial'naja disfunkcija i ee prognosticheskoe znachenie pri kriticheskih sostojanijah v rezul'tate dorozhno-transportnogo travmatizma. Sovremennye problemy nauki i obrazovanija. 2014; 6. Dostupno po ssylke: http://science-education.ru/ru/article/view?id=16629 (data obrashhenija: 24.03.2019). Russian. 
15. Scharpfenecker M, Fiedler U, Reiss Y, Augustin HG. The Tie-2 ligandangiopoietin-2 destabilizes quiescent endothelium through an internal autocrine loop mechanism. J Cell Sci. 2005; 118 (4): 771-80.

\section{Литература}

1. Dumnicka P, Maduzia D, Ceranowicz P, et al. The Interplay between Inflammation, Coagulation and Endothelial Injury in the Early Phase of Acute Pancreatitis: Clinical Implications. Int J Mol Sci. 2017; 18 (2): E354. DOI: 10.3390/ijms18020354. PubMed PMID: 28208708.

2. Алексеев А. А., Ушакова Т. А., Крутиков М. Г., Бобровников А. Э. Маркеры сепсиса в диагностике адаптивного воспаления при ожоговой травме. Лечение и профилактика. 2015; 2 (14): 84-91.

3. Ушакова Т. А. Адаптация к ожоговой травме: проблемы и перспективы. Комбустиология. 2009; 39. Доступно по ссылке: www.combustiolog.ru (дата обращения 23.06.2018).

4. Chousterman BG, Swirski FK, Weber GF. Cytokine storm and sepsis disease pathogenesis. Semin Immunopathol. 2017; 39 (5): 517-28.

5. Ince C, Mayeux PR, Nguyen T, et al. The endothelium in sepsis. Shock. 2016; 45 (3): 259-70.

6. Abdel-Hafez NM, Saleh Hassan Y, El-Metwally TH. A study on biomarkers, cytokines, and growth factors in children with burn injuries. Ann Burns Fire Disasters. 2007; 20 (2): 89-100.

7. Петрищев Н. Н., Беркович О. А., Власов Т. Д. и др. Диагностическая ценность определения десквамированных эндотелиальных клеток в крови. Клиническая лабораторная диагностика. 2001; (1): 50-2.

8. Гавриленко Т. И., Рыжкова Н. А., Пархоменко А. Н. Сосудистый эндотелиальный фактор роста в клинике внутренних заболеваний и его патогенетическое значение. Український кардіологічний журнал. 2011; (4): 87-95.

9. Erdbruegger U, Haubitez M, Woywodt A. Circulating endothelial
16. Abo El-Noor MM, Elgazzar FM, Alshenawy HA. Role of inducible nitric oxide synthase and interleukin- 6 expression in estimation of skin burn age and vitality. J Forensic Leg Med. 2017; (52): 148-53.

cells: a novel marker of endothelial damage. Clinica Chimica Acta. 2006; (373): 17-26.

10. Дремина Н. Н, Шурыгин М. Г., Шурыгина И. А. Эндотелины в норме и патологии. Международный журнал прикладных и фундаментальных исследований. 2016; (10): 210-14.

11. Yanagisawa M, Masaki T. Molecular biology and biochemistry of the endothelins. Trends Pharmacol Sci. 1989; 10 (9): 374-8.

12. Моррисон В. В., Божедомов А. Ю. Дисфункция эндотелия при синдроме полиорганной недостаточности у больных с термической травмой. Регионарное кровообращение и микроциркуляция. 2013; 2 (46): 43-8.

13. Iba T, Kidokoro A, Fukunaga M, et al. Association between the severity of sepsis and the changes in hemostatic molecular markers and vascular endothelial damage markers. Shock. 2005; 23 (1): 25-9.

14. Фирсов С. А., Матвеев Р. П. Эндотелиальная диссфункция и ее прогностическое значение при критических состояниях в результате дорожно-транспортного травматизма. Современные проблемы науки и образования. 2014; 6. Доступно по ссылке: http://science-education.ru/ru/article/view?id=16629 (дата обращения: 24.03.2019).

15. Scharpfenecker M, Fiedler U, Reiss $Y$, Augustin HG. The Tie-2 ligandangiopoietin-2 destabilizes quiescent endothelium through an internal autocrine loop mechanism. J Cell Sci. 2005; 118 (4): $771-80$.

16. Abo El-Noor MM, Elgazzar FM, Alshenawy HA. Role of inducible nitric oxide synthase and interleukin-6 expression in estimation of skin burn age and vitality. J Forensic Leg Med. 2017; (52): 148-53. 